\title{
Tecticornia globulifera and T. medusa (subfamily Salicornioideae: Chenopodiaceae), two new priority samphires from the Fortescue Marsh in the Pilbara region of Western Australia
}

\author{
Kelly A. Shepherd ${ }^{1,2}$ and Stephen J. van Leeuwen ${ }^{3}$ \\ ${ }^{1}$ Western Australian Herbarium, Department of Environment and Conservation, \\ Locked Bag 104, Bentley Delivery Centre, Western Australia 6983, Australia. \\ ${ }^{2}$ School of Plant Biology, The University of Western Australia, 35 Stirling Highway, \\ Crawley, Western Australia 6009, Australia. \\ ${ }^{3}$ Wildlife Research Centre, Department of Environment and Conservation, \\ PO Box 51, Wanneroo, Western Australia 6946, Australia. \\ Author for correspondence: Kelly.Shepherd@dec.wa.gov.au
}

\begin{abstract}
Salt lakes are common across inland Australia but within the Pilbara region, in the north west of Western Australia, saline habitats are infrequent. Fortescue Marsh is the predominant saline system in this region and two new species of conservation interest have been found to occur only on the Marsh and Weelarrana Lake south of Newman. Tecticornia globulifera K.A.Sheph. sp. nov. and T. medusa K.A.Sheph. \& S.J.van Leeuwen sp. nov. are formally named and described herein. Images of these new species and a distribution map are included.
\end{abstract}

\section{Introduction}

The episodically inundated Fortescue Marsh is situated in the Fortescue Valley Interim Biogeographic Regionalisation for Australia (IBRA) subregion (PIL2) between the Chichester and Hamersley Ranges approximately $110 \mathrm{~km}$ NNW of Newman. This Marsh is almost $100 \mathrm{~km}$ long and is $21 \mathrm{~km}$ across at its widest point, covering a total area of $978 \mathrm{~km}^{2}$, provides a significant seasonal habitat for waterbirds (Halse et al. 2005) and is the contemporary locality for a confirmed sighting of the elusive, Critically Endangered Night Parrot (Pezoporus occidentalis) (Davis and Metcalf 2008). As this is one of the largest and most important wetlands in the Pilbara region, the Fortescue Marsh is listed on the Directory of Important Wetlands of Australia as a wetland of national and regional significance (WA066) (Kendrick 2001). The Marsh was recognised as a Priority High Conservation Value Aquatic Ecosystem (HCVAE) in the 2009-10 Caring for our Country business plan (Commonwealth of Australia 2010) 
and is cited as an Indicative Place on the Register of the National Estate (Department of the Environment, Water, Heritage and the Arts 2010). A significant part $\left(766 \mathrm{~km}^{2}\right)$ of the Fortescue Marsh will be added to the conservation estate in 2015 when portions of Marillana, Roy Hill, Hillside and Mulga Downs Stations are excised from the pastoral estate during the lease renewal process.

Plant species of conservation significance recorded from the Fortescue Marsh and the fringing mulga woodland apron include the Priority One species Myriocephalus scalpellus Paul G.Wilson, Calocephalus beardii P.S.Short ms, Nicotiana heterantha Symon \& Kenneally and Eremophila spongiocarpa Chinnock as well as the Priority Three Atriplex flabelliformis Paul G.Wilson, Priority Four Eremophila youngii subsp. lepidota Chinnock and Goodenia nuda E.Pritz. Two of these species, namely Myriocephalus scalpellus and Eremophila spongiocarpa, are endemic to the Marsh. The Marsh also supports a unique samphire community that includes four currently undescribed phrase named species of Tecticornia. Three of these, T. sp. Fortescue Marsh (K.A. Shepherd et al. KS1055), T. sp. Roy Hill (H. Pringle 62) (described herein as T. globulifera K.A.Sheph. and T. medusa K.A.Sheph. \& S.J.van Leeuwen respectively) and T. sp. Christmas Creek (K.A. Shepherd \& T. Colmer et al. KS 1063) are taxa of conservation concern that are currently only known from the Marsh and from Weelarrana Lake, which is a small lake around $80 \mathrm{~km}$ south of Newman. The fourth taxon, T. sp. Dennys Crossing (K.A. Shepherd \& J. English KS 552), has a widespread distribution across Western Australia. It is of interest, that while T. sp. Roy Hill (H. Pringle 62) is readily distinguished by its large, bright green articles and long inflorescences, this species had only been collected twice in the 1990s and it was not collected during flora surveys that focused in part on the Marsh (Newbey \& Newbey 1991; Mattiske Consulting Pty Ltd 2005). This is probably due to the fact that this species occurs quite some distance from the outer fringes of the Marsh, in situations that experience extended periods of inundation. Prior to this study T. sp. Fortescue Marsh (K.A. Shepherd et al. KS1055) (PERTH 02668459) had previously only been collected once during a survey in 1991 but due to a lack of adequate fertile material it was determined as Halosarcia sp. (KRN 10243) (Newbey \& Newbey 1991) and its status could not be resolved. Tecticornia sp Christmas Creek (K.A. Shepherd \& T. Colmer et al. KS 1063) was also only recently discovered and further collections are required to resolve its status in relation to allied species such as the widespread and variable T. undulata (Paul G.Wilson) K.A.Sheph. \& Paul G.Wilson.

Interest in the samphire community of the Fortescue Marsh has increased in recent years with the development of a number of mines on the north side of the Marsh, which are extracting Marra Mamba iron ore from the southern foothills of the Chichester Ranges. Currently two operational mines (Fortescue Metals Group (FMG) Limited Cloud Break and Christmas Creek mines) and one under development (Hancock Prospecting Pty Ltd Roy Hill project) occur in the area. Changes to groundwater and surface hydrological regimes associated with mining operations have significantly increased concerns about the impacts on the healthy function of the Marsh and its samphire community. These impacts may include altered flow patterns and flow rates due to the construction of infrastructure, groundwater levels influenced by aquifer drawdown and aquifer re-injection, and the impact on water quality through the discharge of excess groundwater to the surface.

While samphires are recognised as 'halophytes' meaning they are salt-loving, species actually exhibit differences in salinity tolerance, water use and ability to survive periods of inundation (Short \& Colmer 1999, English 2004, Pedersen et al. 2006). Consequently, 
there can be distinct patterns of species zonation around the margins of ephemeral salt lakes (Datson 2002, English 2004). This is clearly evident at Fortescue Marsh as T. indica subsp. bidens (Nees) K.A.Sheph. \& Paul G. Wilson tends to dominate on the more well-drained outer fringes, whereas the distinct glaucous T. auriculata (Paul G.Wilson) K.A.Sheph. \& Paul G.Wilson occurs in more waterlogged soil towards the inner areas of the marsh away from the shoreline.

The University of Western Australia in conjunction with FMG and the Western Australian Herbarium (PERTH) have recently undertaken an Australian Research Council Linkage Project. This research involves studying the ecophysiology of a range of samphire species on the Fortescue Marsh to distinguish the impacts of natural dynamics of changing water regimes from potential mine-related effects. During a preliminary visit to potential study sites on the Fortescue Marsh, populations of T. sp. Roy Hill (H. Pringle 62) were discovered growing some distance from the shore and hence it is apparent that this species is able to withstand extended periods of waterlogging. Therefore, this taxon was selected as one of the focus species for the ARC-linkage study along with T. indica subsp. bidens and T. auriculata. As T. sp. Roy Hill (H. Pringle 62) is to be included in further studies and due to the increase in potential threats with increased mining and exploration activity in the area, it was considered a priority to name both this species and T. sp. Fortescue Marsh (K.A. Shepherd et al. KS1055).

\section{Methods}

Herbarium specimens lodged at PERTH and spirit material preserved in $70 \%$ ethanol were examined for this study. All measurements were made using callipers or with a microscope eye piece graticule. Terminology used to describe the shape of the floral bracts follows Shepherd (2007). The seed image was produced using an Environmental Scanning Electron Microscope at the Centre for Microscopy, Characterisation and Analysis, University of Western Australia (Danilastos 1993). The species distribution map was produced using MapInfo software and DIVA-GIS Version 5.2.0.2. (http://www. diva-gis.org/). The map also includes the IBRA categories Version 6.1 (Department of the Environment, Water, Heritage and the Arts 2008) as modified on FloraBase. Species described in this paper have a conservation priority and therefore their precise localities have been withheld.

\section{Taxonomy}

\section{Tecticornia globulifera K.A.Sheph. sp. nov.}

Differt a Tecticornia pergranulata (J.M.Black) K.A.Sheph. \& Paul G.Wilson articulis terminalibus globosis, seminibus granularibus rubiginosis.

Type: Western Australia: Fortescue Marsh [precise locality withheld for conservation reasons], K.A. Shepherd, T. Colmer, G. Barrett \& J. McHattie KS 1060, 16 Nov 2006; holo. PERTH7484828; iso. AD, MEL.

Tecticornia sp. Fortescue Marsh (K.A. Shepherd KS 1055 et al.) Western Australian Herbarium (1988+).

Perennial shrub to $0.3-0.5 \mathrm{~m}$ high. Vegetative articles globular to obovoid, not compressed, 
green or pink to red, 1.5-7(-11) mm long, 2.1-5.5 mm wide, epidermis smooth, dull, apex truncate, margin entire. Inflorescence 5-16(-22) $\mathrm{mm}$ long, 2-4.5 $\mathrm{mm}$ wide, forming a spike 3-9 nodes long, cylindrical, with a sinuate outline; terminal to main or lateral branches; florets in each 3-flowered cyme bisexual. Bracts obovoid, fused, cylindrical or convex in face view with the upper edge straight to shallowly curved, cylindrical or concave in the side view with the upper edge straight or shallowly curved, outer face of bract flat to slightly rounded, epidermis smooth, dull; apex truncate, margin entire; upper bracts free from subtending bracts. Flowers exposed above subtending bracts; free from bracts above and below, free from adjacent florets. Perianth fused, the adaxial surface horizontal to shallowly ascending, abaxial surfaces horizontal to shallowly

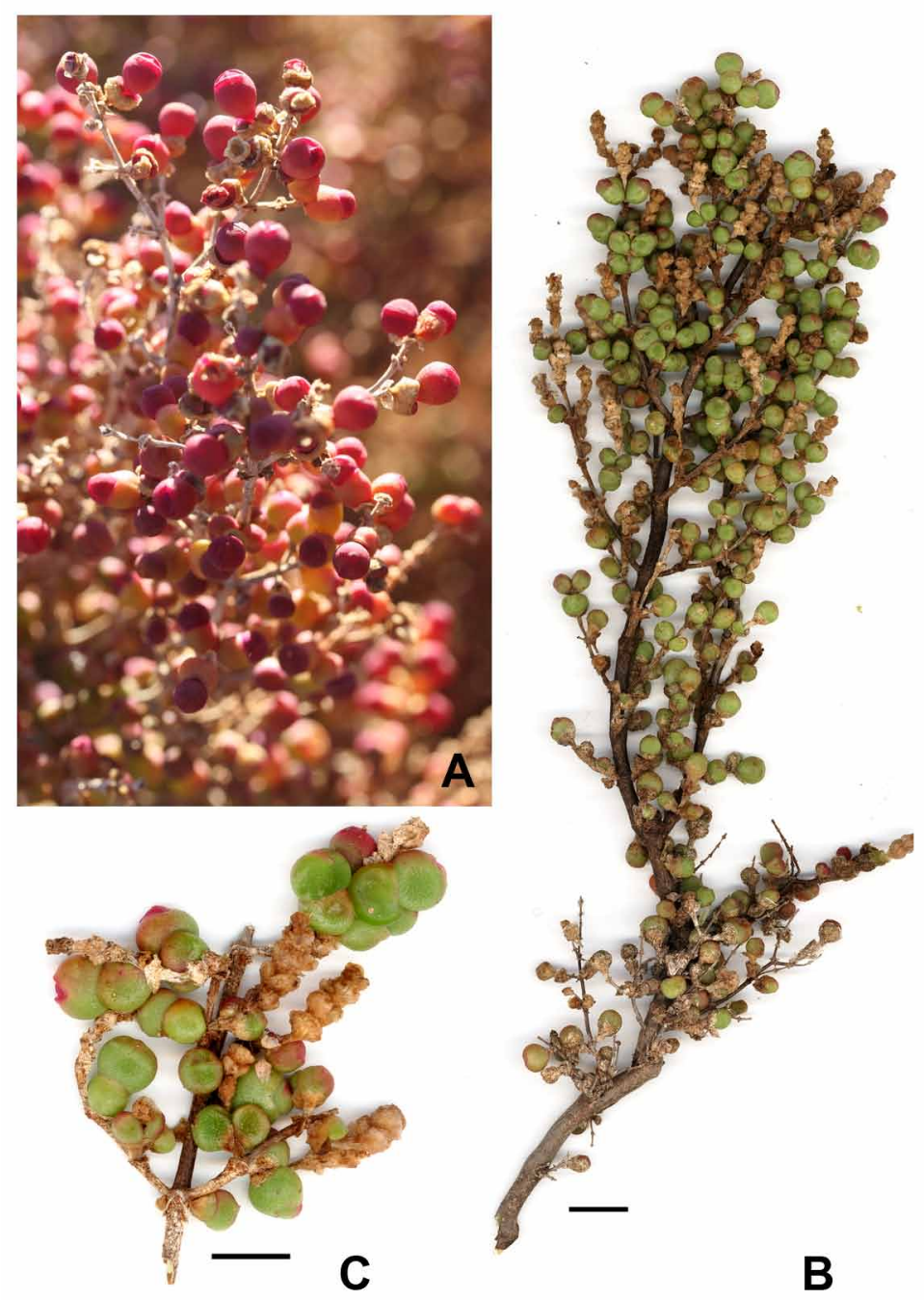

Fig.1. Tecticornia globulifera. a, habit; b, branchlet; c, globular articles and light brown mature inflorescences (K.A. Shepherd, L. Moir-Barnetson et al. KS 1079). Scale bars $=10 \mathrm{~mm}$. 
ascending, laterally square or sometimes rounded, apex truncate; lobes 3 , with a small, rounded abaxial lobe inside two lateral lobes, margins entire. Stamen 1; anther oblong, $0.8-1.1 \mathrm{~mm}$ long. Ovary free from the stem cortex; style bifid, membranous. Fruiting spike scarcely expanded, papery. Apical vegetative growth absent or rarely present. Fruitlets exposed above subtending bracts, free from bracts above and below, free from lateral fruits; fruiting perianth laterally square or rounded, apex truncate, papery, fused with pericarp, style at fruiting stage absent. Pericarp not enclosing seed, not dehiscing in medial plane. Seed free from pericarp, horizontal relative to stem axis, rounded to ovate with a flattened upper margin and rounded base, small beak, 1-1.3 mm long, opaque, red-brown and faintly granular all over. (Fig. 1)

Flowering. Material has been observed in flower from August and fruits begin to mature in November.

Selected specimens examined: Western Australia: M.N. Lyons \& D.A. Mickle 4893, 2 June 2004 (BRI, CANB, PERTH); M.N. Lyons \& D.A. Mickle 4892, 1 Sep 2005 (AD, DNA, K, MEL, NSW, PERTH); M.N. Lyons \& D.A. Mickle 4894, 15 Aug 2006 (CANB, PERTH); M.N. Lyons \& D.A. Mickle 4897, 15 Aug 2006 (AD, CANB, PERTH); K.R. Newbey 10243, 28 Jun 1984 (AD, MEL, PERTH); K.A. Shepherd, T. Colmer, G. Barrett \& J. McHattie KS 1049, 15 Nov 2006 (CANB, HO, PERTH); K.A. Shepherd, T. Colmer, G. Barrett \& J. McHattie KS 1055, 16 Nov 2006 (BRI, DNA, PERTH); K.A. Shepherd, L. Moir-Barnetson et al. KS 1079, 29 May 2008 (PERTH).

Distribution. Western Australia: currently only known from the Fortescue Marsh and Weelarrana Lake in the Pilbara and Gascoyne IBRA regions of the Eremaean Botanical Province (Figure 2).

Habitat. Tecticornia globulifera is found on moderately saline flats on red-brown gritty clay associated with other samphire species.

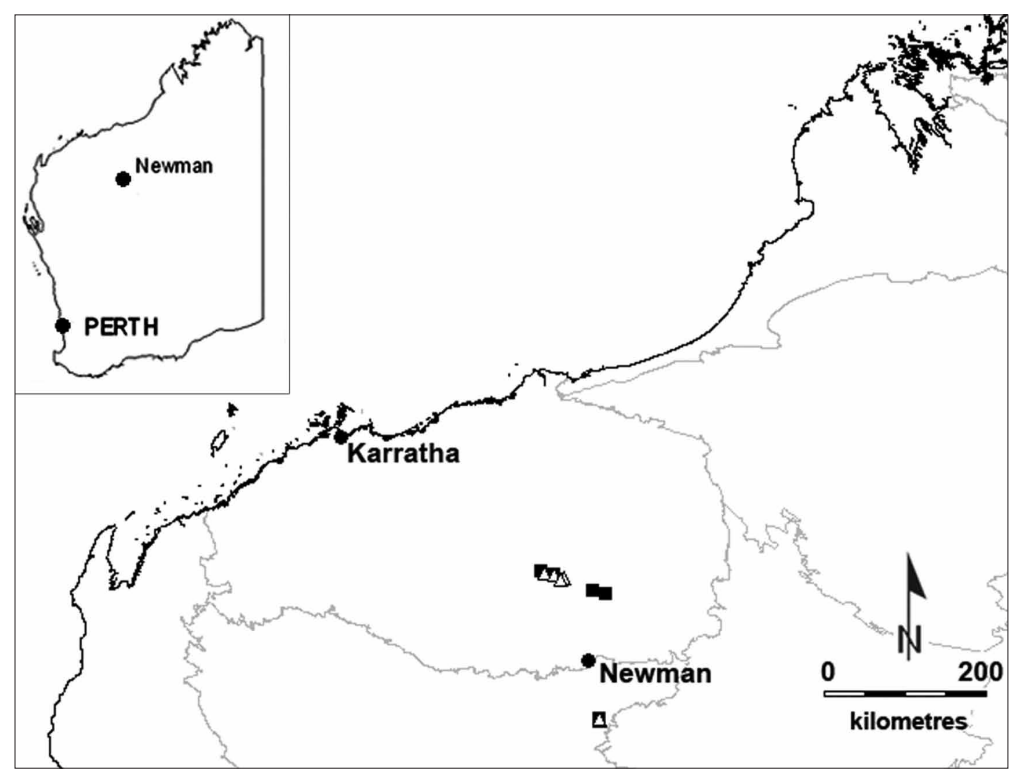

Fig.2. Western Australian distribution of Tecticornia globulifera $(\triangle)$ and T. medusa $(\mathbf{\square})$ with IBRA regions Version 6.1 in grey (Department of the Environment, Water, Heritage and the Arts 2008). 
Conservation status. This species is currently only known from two saline systems and therefore has a Priority One - Poorly Known Taxa conservation status, as defined by the Department of Environment and Conservation (DEC) Conservation Codes for Western Australian Flora. This status is accorded to a taxon when there are one or few (generally $<5$ ) populations that are considered to be under threat but the taxon can not yet be declared as 'rare flora' as further survey is required. Under the IUCN Red List Categories and Criteria this species would therefore be placed in the 'Data Deficient' category (IUCN Standards and Petitions Subcommittee 2010).

As a large part of the Marsh will become a conservation reserve in 2015 the status for this taxon may change to Priority Two in the future.

Etymology. This epithet is derived from the Latin globulus (little ball) and fero (to bear) in reference to its distinct globular articles.
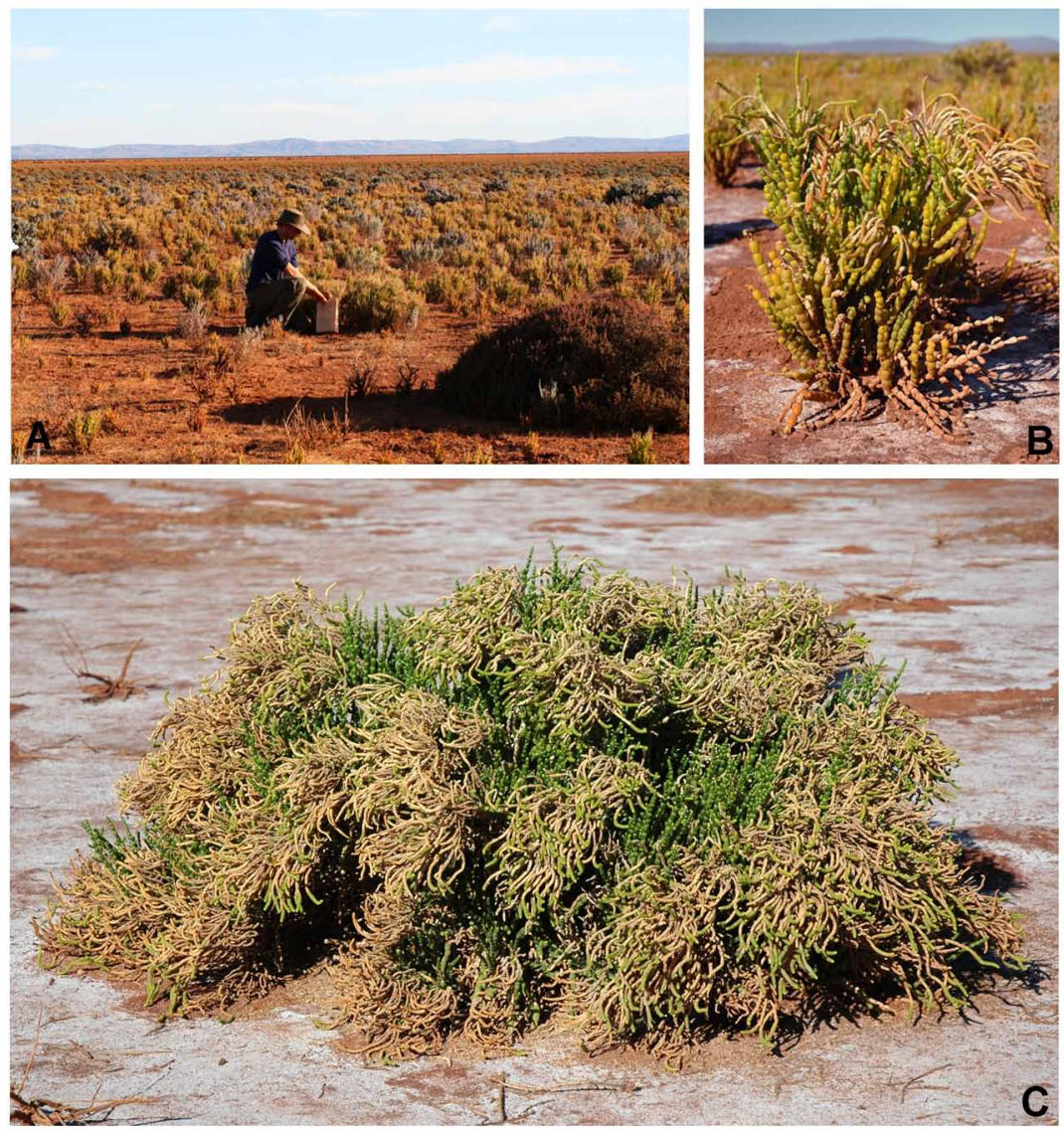

Fig.3. Tecticornia medusa. a, Louis Moir-Barnetson collecting seed for glasshouse trials from a large population of T. medusa on Fortescue Marsh; b, habit of a young plant showing the inflorescences are much narrower than the large subtending vegetative articles; c, older plant with a mass of 'snake-like' mature inflorescences. Photographs a, K.A. Shepherd; b, c, K.R. Thiele. 
Affinity. Tecticornia globulifera is similar to T. pergranulata and entities within the T. halocnemoides complex (Wilson 1980; Shepherd \& Lyons 2009, see Affinity section pg 177) but is readily distinguished by its obvious terminal globular articles. This species does not have long succulent, vegetative branches and it is apparent that articles wither and slough away relatively quickly, leaving the terminal 'balls' for which this species is named. T. globulifera also differs from T. pergranulata by virtue of its red-brown seeds that are granular all over. T. pergranulata has long vegetative branches of cylindrical or obovoid articles and dark brown or black seeds with concentric rings of dense rounded protrusions (Shepherd et al. 2005).

Notes. Mature seed embryo not seen for this species.

\section{Tecticornia medusa K.A.Sheph. \& S.J.van Leeuwen sp. nov.}

Tecticorniae halocnemoidi subsp longispicatae (Paul G.Wilson) K.A.Sheph. \& Paul G.Wilson affini, sed articulis magnis viridibus, inflorescentia angustata, seminibus ovatis rubiginosis $1-1.1 \mathrm{~mm}$ longis notabilis.

Type: Western Australia: Fortescue Marsh [precise locality withheld for conservation reasons], K.A. Shepherd, T. Colmer, G. Barrett, J. McHattie KS 1048a, 15 Nov 2006; holo. PERTH7462824; iso. CANB, MEL, K.

Halosarcia sp. Roy Hill (H. Pringle 62); Tecticornia sp. Roy Hill (H. Pringle 62); Western Australian Herbarium (1998+).

Perennial shrub to $0.3-0.7 \mathrm{~m}$ high. Vegetative articles obovoid to cylindrical, not compressed, bright green, 4-17 mm long, 4.5-13 mm wide, epidermis smooth, dull or slightly glossy, apex truncate, margin entire. Inflorescence 11-43 mm long, 2.5-4.5 mm wide, forming a spike 10-32 nodes long, narrowly cylindrical, with a smooth outline, terminal to main or lateral branches; florets in each 3-flowered cyme bisexual. Bracts fused, cylindrical or slightly convex in face view with the upper edge straight or shallowly curved, cylindrical or slightly convex in side view with the upper edge straight or shallowly curved, outer face of bract flat or slightly rounded, epidermis smooth, dull or slightly glossy; apex truncate or slightly acute, margin entire; upper bracts free from subtending bracts. Flowers partially exposed above subtending bracts; free from bracts above and below, free from adjacent florets. Perianth fused, the adaxial surface horizontal or shallowly ascending, abaxial surfaces horizontal to shallowly ascending, laterally square, apex truncate; lobes 3, with a small, rounded abaxial lobe inside two lateral lobes, margins entire. Stamen 1; anther oblong, $0.6-0.8 \mathrm{~mm}$ long, abaxial to the ovary. Ovary free from the stem cortex; style bifid, membranous. Fruiting spike not expanded, papery. Apical vegetative growth absent. Fruitlets exposed above subtending bracts, free from bracts above and below, free from lateral fruits; fruiting perianth laterally square, apex truncate, papery, fused with the pericarp, style at fruiting stage absent. Pericarp not enclosing seed, not dehiscing in medial plane. Seed free from the pericarp, horizontal to shallowly ascending relative to stem axis, rounded with a small beak, $1-1.1 \mathrm{~mm}$ long, opaque, light gold brown with 3 to $4(-4.5)$ rows of small bumps on the outer margin and towards centre of seed, sides smooth and shiny. Embryo curved, lateral perisperm present. (Figs 3 \& 4)

Flowering. Material seen in flower from July and November. Mature fruits were observed in May. 
Selected specimens examined: Western Australia: M.N. Lyons \& D.A. Mickle 4895, 3 Jun 2004 (DNA, NSW, PERTH ); M.N. Lyons \& D.A. Mickle 4898, 3 Jun 2004 (BRI, PERTH ); M.N. Lyons \& D.A. Mickle 4899, 1 Sep 2005 (AD, BRI, HO, MEL, NSW, NY, PERTH); M.N. Lyons \& D.A. Mickle 4900, 15 Aug 2006 (CANB, PERTH); A.A. Mitchell 1834, 8 Apr 1990 (PERTH); A.A. Mitchell PRP 1287, 27 Jul 1996 (CANB, PERTH); H. Pringle 62, 3 Nov 1990 (PERTH); K.A. Shepherd, T. Colmer, G. Barrett, J. McHattie KS 1048b, 15 Nov 2006 (DNA, K, PERTH); K.A. Shepherd, T. Colmer, G. Barrett, J. McHattie KS 1056, 16 Nov 2006 (AD, HO, NSW, PERTH); K.A. Shepherd, T. Colmer, G. Barrett, J. McHattie KS 1057, 16 Nov 2006 (MO, PERTH); K.A. Shepherd, L. Moir-Barnetson et al. KS 1084, 29 May 2008 (PERTH).

Distribution. This species is restricted to the floodplains of Fortescue Marsh and Weelarrana Lake south of Weelarrana Hill, in the Pilbara and Gascoyne IBRA regions of the Eremaean Botanical Province (Fig. 2).

Habitat. Tecticornia medusa grows in red-brown gritty clay on a saline alluvial plain and is found in dense populations some distance from the shoreline. This area is likely to be inundated for longer periods and it is hypothesised that this species is more tolerant of waterlogging than other species found in the area.

Conservation status. This species has Priority Three - Poorly Known Taxa conservation status as defined by the Department of Environment and Conservation (DEC) Conservation Codes for Western Australian Flora, as it is currently known from a number of populations on the Fortescue Marsh and Weelarrana Lake approximately $160 \mathrm{~km}$ to the south. This category relates to taxa that are known from several populations, at least some of which are not believed to be under immediate threat. Like other priority taxa it can not be declared as 'rare flora' until further population
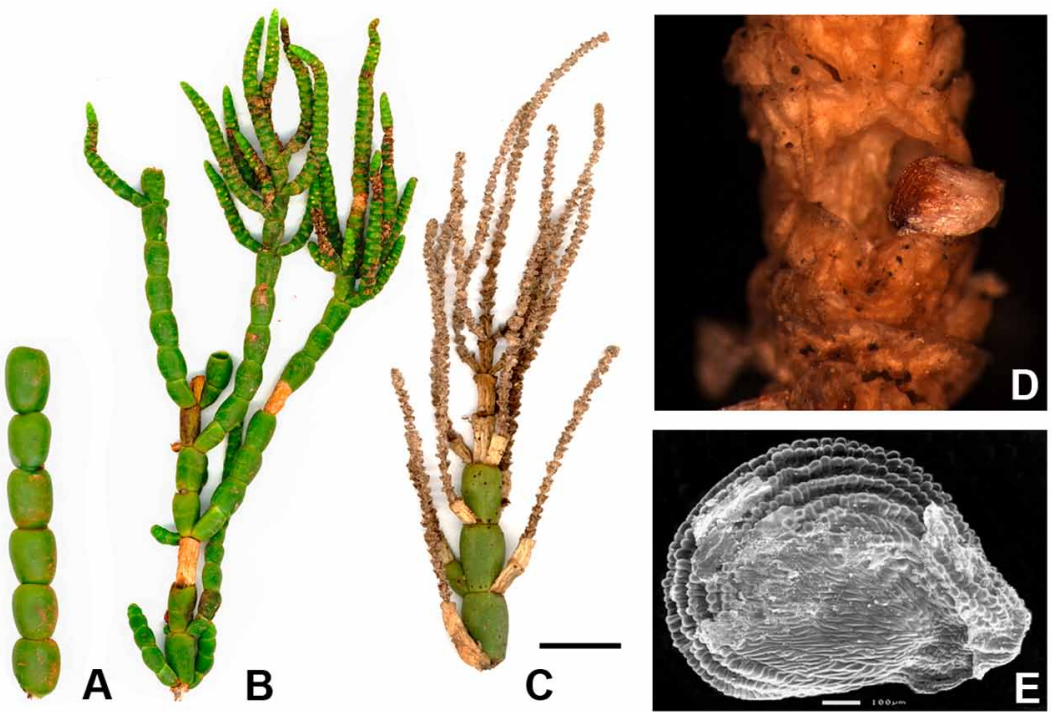

Fig.4. Tecticornia medusa. a, vegetative articles; b, vegetative branches and inflorescences; c, light brown mature inflorescences; $\mathbf{d}$, close up of laterally square fruit with base of the red-brown seed exposed; e, seed in detail showing rows of rounded protrusions on the outer margin. (a-d K.A. Shepherd, T. Colmer, G. Barrett, J. McHattie KS 1048b; e, H. Pringle 62). Scale bar: a-c $=10 \mathrm{~mm}$, $\mathrm{d}=0.8 \mathrm{~mm} ; \mathrm{e}=100 \mu \mathrm{m}$. 
survey and monitoring has been undertaken. Consequently, under the IUCN Red List Categories and Criteria this species would be categorised as 'Data Deficient' (IUCN Standards and Petitions Subcommittee 2010).

Etymology. At maturity, the long terminal inflorescences of this species may become curved and twisted, reminiscent of Medusa the Gorgon of Greek mythology whose hair was a mass of living venomous snakes. The epithet is used as a noun in apposition.

Affinity. Tecticornia medusa is similar to entities within the T. halocnemoides subsp. longispicata (Paul G.Wilson) K.A.Sheph. \& Paul G.Wilson complex (Wilson 1980) and T. sp. Lake Way (P. Armstrong 05/961) by virtue of its long inflorescences and the pithy, laterally square fruits and ornamented seeds. It is readily distinguished from other samphires by its much larger articles (4-17 $\mathrm{mm}$ long). These stand out as the inflorescences appear much narrower than the subtending articles. The seeds of T. medusa are red-brown, ovate and $1-1.1 \mathrm{~mm}$ long with 3 to $4(-4.5)$ rows of small bumps on the outer margin and smooth sides. There is considerable variation within T. halocnemoides subsp. longispicata, which requires further taxonomic work, however the articles of this group are smaller and generally less than $5 \mathrm{~mm}$ long. Tecticornia sp. Lake Way (P. Armstrong 05/961) has articles that are 4-7 mm long and the seeds of this taxon are roundish, light brown in colour and $0.8 \mathrm{~mm}$ long. There are 3(-3.5) rows of small rounded protrusions on the outer margin and the sides of the seed are smooth.

\section{Acknowledgments}

This paper is dedicated to the late, great, Surrey Jacobs (1946-2009), who had a long term research interest in the Australian chenopods. Surrey examined the $\mathrm{PhD}$ thesis of the lead author (Shepherd 2005) and wrote during a recent email exchange discussing the systematic position of Chenopodiaceae "It is a specialist world. None of us can hope to be on top of everything" and yet, Surrey himself managed to work successfully on a wide range of plant groups throughout his long and productive career, for which we are grateful. The authors would also like to thank Tim Colmer, Erik Veneklaas, Bob Bromilow, Louis Moir-Barnetson, Jeremy McHattie and Greg Barrett for support in the field. This research is funded in part through an ARC-linkage grant based at The School of Plant Biology, University of Western Australia (UWA) with support from Fortescue Metals Group (FMG) Limited and the Western Australian Herbarium, DEC. Funding was also provided through a 'DEC' specific nature conservation project grant (20092010) within the Nature Conservation Service (formerly labelled as the Biodiversity Conservation Initiative). The authors acknowledge Paul Wilson for confirming the Latin diagnoses.

\section{References}

Commonwealth of Australia (2010) Caring for our Country 2009-10 business plan. http://www. nrm.gov.au/business-plan/09-10/info-sheets.html\#targets (Accessed February 2010)

Danilastos GD (1993) Microscopy research and technique. Pp. 354-361 in Johnson JE (ed.) Introduction to the environmental scanning electron microscope instrument. (Wiley-Liss: New York)

Datson B (2002) Samphires in Western Australia. (Department of Conservation and Land Management: Perth) 
Davis RA \& Metcalf BM (2008) The Night Parrot (Pezoporus occidentalis) in northern Western Australia: a recent sighting from the Pilbara Region. Еmu 108: 233-236.

Department of the Environment, Water, Heritage and the Arts (2008) Interim Biogeographic Regionalisation for Australia (IBRA), Version 6.1 http://www.environment.gov.au/parks/nrs/ science/bioregio-framework/ibra/index.html. (Accessed December 2008)

Department of the Environment, Water, Heritage and the Arts (2010) Australian Heritage Database: Fortescue Marshes, Roy Hill, WA, Australia, http://www.environment.gov.au/cgibin/ahdb/search.pl?mode=place_detail;place_id=101319 (Accessed February 2010)

English JP (2004) Ecophysiology of salt- and waterlogging-tolerance in selected species of Halosarcia. (PhD Thesis: The University of Western Australia)

Halse SA, Pearson GB, Hassell C, Collins P, Scanlon MD \& Minton CDT (2005) Mandora Marsh, north-western Australia, an arid zone wetland maintaining continental populations of waterbirds. Emu 105: 115-125.

IUCN Standards and Petitions Subcommittee (2010) Guidelines for Using the IUCN Red List Categories and Criteria. Version . Prepared by the Standards and Petitions Subcommittee in March 2010. http://intranet.iucn.org/webfiles/doc/SSC/RedList/RedListGuidelines.pdf (Accessed May 2010)

Kendrick P (2001) Pilbara 2 (PIL2 - Fortescue Plains subregion). http://www.dec.wa.gov.au/ science-and-research/biological-surveys/a-biodiversity-audit-of-wa.html (Accessed August 2009)

Mattiske Consulting Pty Ltd (2005) Flora and vegetation on the Cloud Break and White Knight Leases. (Mattiske Consulting Pty Ltd: Perth)

Newbey KR \& Newbey BJ (1991) Vegetation and flora of part of the Fortescue samphire flat, Pilbara region, Western Australia. (Newbey KR \& Newbey BJ: Perth)

Pedersen O, Vos H \& Colmer TD (2006) Oxygen dynamics during submergence in the halophytic stem succulent Halosarcia pergranulata. Plant, Cell and Environment 29: 1388-1399.

Shepherd KA (2007) Three new species of Tecticornia (formerly Halosarcia) (Chenopodiaceae: Salicornioideae) from the Eremaean Botanical Province, Western Australia. Nuytsia 17: 353-366.

Shepherd KA \& Lyons MN (2009) Three new species of Tecticornia (Chenopodiaceae, subfamily Salicornioideae) identified through Salinity Action Plan surveys of the wheatbelt region, Western Australia. Nuytsia 19: 167-180.

Shepherd KA, Colmer TD \& Macfarlane TD (2005) Morphology, anatomy and histochemistry of fruits and seeds of the Salicornioideae (Chenopodiaceae). Annals of Botany 95: 917-933.

Short DC \& Colmer TD (1999) Salt Tolerance in the Halophyte Halosarcia pergranulata subsp. pergranulata. Annals of Botany 83: 207-213.

Western Australian Herbarium (1998+) FloraBase — The Western Australian Flora. Department of Environment and Conservation. http://florabase.dec.wa.gov.au/ (Accessed September 2009)

Wilson PG (1980) A revision of the Australian species of Salicornieae (Chenopodiaceae). Nuytsia 3: 1-154. 